УДК: 658.9

Битов В.П., к.е.н., доцент

Кадебська Е.В., к.е.н.

Волинський інститут ім. В.Липинського МАУП

\title{
УПРАВЛІННЯ КОНКУРЕНТОСПРОМОЖНІСТЮ ПРОДУКЦІї ПІДПРИЕМСТВ В РИНКОВИХ УМОВАХ
}

У публікації розглянуто роль і значення конкуренції та управління конкурентоспроможністю продукції підприємств в умовах ринку, що $є$ сьогодні досить актуальним і своєчасним. Обрана тема публікації полягає у тому, що через підвищення менеджменту конкурентоспроможністю українських підприємств дає можливість значно збільшити сегмент обсягу виробництва та реалізації продукції та послуг як на зовнішньому так і на внутрішньому ринку. У даній публікації охарактеризовано окремі види конкуренції та їх дієвість і значення, а також виділено основні напрямки цілеспрямованої діяльності, які передбачають застосування нових підходів і форм щодо менеджменту, як дієвої форми управління конкурентоспроможністю підприємств в ринкових умовах. Запропоновано також окремі механізми розрахунку щодо забезпечення можливості підвищення конкурентоспроможності, що сприятиме ефективному розвитку підприємств в умовах ринку.

Ключові слова: підприємство, менеджмент, конкуренція, підприємництво, матеріальні ресурси, прибуток, ціна, цінова конкуренція, ринкова економіка, конкурентоспроможність.

Bitov V., Kadebskaya E.

\section{MANAGEMENT OF COMPETITIVENESS OF ENTERPRISES IN MARKET CONDITIONS}

The publication examines the role and importance of management as a convincingly effective way of managing the competitiveness of enterprises in a market environment that is quite relevant and timely today. The chosen topic of the publication is that, by improving the management of the competitiveness of Ukrainian enterprises, it is possible to significantly increase the segment of sales of products and ambassadors both in the external and internal markets. This post highlights the main areas of focus targeted activities that involve the use of new approaches and forms to show the growing range of competition for products and services and accelerate the pace of change according to market parameters. Separate mechanisms are proposed for the possibility of increasing competitiveness, which will contribute to the effective development of enterprises in the market.

Keywords: enterprise, management, competition, entrepreneurship, material resources, profit, price, price competition, market economy.

Бытов В.П., Кадебская Е.В.

\section{УПРАВЛЕНИЕ КОНКУРЕНТОСПОСОБНОСТЬЮ ПРЕДПРИЯТИЙ В РЫНОЧНЫХ УСЛОВИЯХ}

В публикации рассматриваются роль и значение менеджмента как убедительно эффективного способа управления конкурентоспособностью продукции предприятий в рыночной среде, что является весьма актуальным и своевременным на сегодняшний день. Выбранная тема публикации заключается в том, что, улучшая управление конкурентоспособностью украинских предприятий, можно значительно увеличить сегмент продаж продукции как на внешнем, так и на внутреннем рынках. . В данной публикации выделены основные действующие направления целенаправленной деятельности, предусматривающих применение новых подходов и форм по увеличению все более широкого круга конкуренции продукции и услуг и ускорения темпов изменений в соответствии с параметрами рынка. Предложено отдельные механизмы относительно возможности повышения конкурентоспособности, что будет способствовать эффективному развитию предприятий в условиях рынка.

Ключевые слова: предприятие, менеджмент, конкуренция, предпринимательство, материальные ресурсы, прибыль, цена, ценовая конкуренция, рыночная экономика.

Постановка проблеми у загальному вигляді та її зв'язок 3 важливими науковими і практичними завданнями. В даний період, коли відбувається поширення розвитку ринкових відносин, немовби як за вимогою часу відбувається становлення і 
формування конкурентного середовища в національній економіці. Адже сьогодні основними господарями на ринку $є$ ціна, попит, пропозиція, якість та конкуренція, яка до речі збільшує свою нішу в сучасному ринку. А саме тому враховуючи появу численних методів та форм проявлення конкуренції, прискорення iї темпів та змін параметрів викликали об'єктивну необхідність розроблення та втілення на українських підприємствах принципово нових підходів до управління конкурентоспроможністю продукції і формування стратегії підприємства. Адже в нинішніх умовах ефективне функціонування підприємства на ринку визначається конкурентоспроможністю товарів, які нею виробляються, а також відповідно наданих нею послуг. На нашу думку дана тема дослідження, що присвячена питанню управління конкурентоспроможністю підприємств $\epsilon$ актуальною і своєчасною. Адже конкуренція сьогодні виступає як головний важіль регулювання економіки, що є надзвичайно важливим, так як забезпечує регулювання ринкових відносин і сприяє розвитку економіки. Щодо питання яке стосується оцінки конкурентоспроможності підприємства то вона, що нами досліджувалося, виражається певною сумою показників. Адже дану категорію оцінки та показники iï рівня вивчають такі науки, як маркетинг, фінанси, економіка підприємства, менеджмент та інші. Кожна 3 них пропонує свої визначення конкурентоспроможності, a також методи ऑii оцінки i шляхи підвищення конкурентоспроможності. [11,c.57 ]. Як свідчать результати вивчення даного питання, , що базові положення теорії конкурентоспроможності та відповідно іiі зв'язок 3 практичними завданнями представлені в наукових працях, які описані в роботах закордонних і вітчизняних учених: О. Батурова, Б. Буркинського, А. Воронкової, В. Диканя, І. Должанського, І. Зулькарнаєва, Ю. Іванова, О. Млоток, В. Павлової, І. Смоліна, О. Тридіда, Х. Фасхієва, К. Щиборща та інших.

Аналіз останніх досліджень і публікацій, у яких започатковано вирішення проблеми. Щодо аналізу останніх досліджень і публікацій, які стосуються питання управління конкурентоспроможністю продукції підприємств в умовах ринку то слід відмітити, що зі зростанням масштабів суспільного виробництва, ускладненням технологічних процесів зростає роль управління конкурентоспроможністю продуктів виробництва, а також послуг, що налає підприємство. За свідченням вчених, які переконують, що науковий аналіз конкуренції стає можливим лише тоді, коли з'ясована внутрішня природа законів ринку, а звідси стає очевидним, що без конкуренції не може бути розвинутого ринку, як і без ринку не буває економічної конкуренції. В нинішніх умовах маркетингові дослідження 3 питань конкурентоспроможності підприємств набувають значної актуальності, через те, що конкурентоспроможність є основним показником ефективного розвитку підприємства. Цьому питанню присвятили багато праць зарубіжні та вітчизняні науковці: І. Ансофф, Ф. Котлер, Г. Брум, А. Сентер, А. А. Джабалов, I. I. Купцов, В. Г. Королько, І. Ю. Слісаренко та інші. Однак вбачаємо за доцільне продовжити вивчення та дослідження даного питання.

Цілі статті. Мета статті полягає у розкритті сутності та значимості конкурентоспроможності підприємств в умовах ринку, адже у конкурентній боротьбі більше уваги приділяється якості продукції, ціні, а також ії дизайну та ін., адже перемагають ті, хто може успішно реалізувати свій товар одержати при цьому прибуток. У даній публікації вважаємо відобразити роль конкуренції в умовах ринку та управління конкурентоспроможністю підприємств, а також існуючі види конкуренції і їх вплив на здатність забезпечувати конкурентоспроможність як виробленої продукції так i відповідно наданих підприємством послуг, що дасть можливість забезпечити досягнення ефективних результатів.

Виклад основного матеріалу дослідження 3 повним обгрунтуванням отриманих наукових результатів. На підставі нами дослідженого слід відмітити, що конкурентоспроможність виробленої підприємством продукції чи наданих ним послуг — це порівняльна характеристика, яка визначає відмінність розглядуваної продукції i 
послуг від продукції і послуг конкурента і містить комплексне оцінювання сукупності їх властивостей з врахуванням вимог ринку. За визначенням науковців конкуренція являє собою антагоністичну форму економічного змагання, суперництво, боротьбу між відокремленими виробниками за свої інтереси. Зовні конкуренція виступає у формі хаотичної боротьби всіх проти всіх. А насправді ж у дійсності вона має свої закономірності, адже для забезпечення конкурентоспроможності в основі ринкової конкуренції $\epsilon$ витрати виробництва. Адже жоден товаровиробник не зможе розвивати виробництво, якщо він продаватиме свої товари за ціною, що нижче витрат виробництва. I особливо зараз, коли відбувається входження господарюючих суб'єктів України 3 виробництва продукції і надання послуг у міжнародний господарський простір.[2,с.64 ]. Адже в умовах глобалізації світової економіки, що супроводжується зростанням конкуренції між країнами за інтернаціоналізовані ринки збуту, загострюються проблеми підвищення рівня конкурентоспроможності вітчизняних підприємств, забезпечення конкурентоспроможності їх продукції і послуг на внутрішньому і зовнішньому ринках. В нинішній період розвитку економіки конкуренція є невід'ємною складовою ринкових відносин, тому вона еволюціонує, як саме поняття, так і методи іiі досягнення на практиці. Тому на нашу думку така економічна категорія як конкуренція i конкурентоспроможність потребує додаткового вивчення та аналізу, адже сьогодні конкуренція є важливим і дієвим механізмом, який забезпечує високу ефективність, пропорційність та динамічність ринкових відносин як у галузі виробництва, так i реалізації продукції.

Сьогодні вимогою часу постає питання забезпечення конкурентоспроможності національного виробника на інноваційній основі, передових технологіях 3 метою досягнення високого рівня випуску продукції та забезпечення прибутку. Як відомо, що сьогодні найважливішим важелем конкуренції виступає ціна і якість на товари і послуги, що реалізуються. Конкурентоспроможності досягає той виробник, хто може продавати продукти та послуги за вигідною для продавця і покупця ціною і одержувати прибуток, адже прибутковий збут грунтується на різниці між їх вартістю та індивідуальними витратами виробництва. Саме тому конкуренція виступає як зовнішня примусова сила, що спонукає товаровиробників підвищувати продуктивність праці на своїх підприємствах, збільшувати нагромадження, розширювати виробництво. [10,с.24 ]. Для того, щоб домогтися забезпечення конкурентоспроможності продукції необхідно застосовувати іï кількісне оцінювання. Без такого оцінювання підтримувати конкурентоспроможність продукції на певному рівні неможливо, оскільки відсутня об'єктивна основа, яка дає змогу говорити про реальний рівень конкурентоспроможності продукції. Адже конкурентоспроможність продукції у загальному вигляді прямо пропорційна якості й обернено пропорційна ціні. Сьогодні в основу оцінювання конкурентоспроможності продукції покладено дослідження потреб споживачів і вимог ринку. Тобто для того щоб об'єктивно оцінити конкурентоспроможність товару на ринку, виробник повинен використовувати такі самі технічні, нормативні та економічні показники, що й споживач. [4,c.36 ].

Щодо видів конкуренції та їх значимості і ролі. Економічна наука в даний час розрізняє декілька видів конкуренції, ми свої дослідження зосередили на таких як внутрігалузеву, міжгалузеву, а також цінову і нецінову конкуренцію. Що стосується внутрігалузевої конкуренції то це конкуренція між виробниками однієї галузі, що виробляють однорідні товари, дбаючи при цьому за найбільш вигідний їх збут i відповідно одержання прибутків. Внутрігалузева конкуренція $є$ вихідною, первісною у загальному механізмі ринкової конкуренції і разом з тим $є$ досить важливою, адже саме вона сприяє забезпеченню стимулювання науково-технічного прогресу i розвитку продуктивних сил. Результати проведених нами досліджень щодо внутрігалузевої конкуренції свідчать, що на різних підприємствах, але однієї галузі, внаслідок відмінностей їх технічного оснащення і технологій формуються індивідуальні витрати 
виробництва різної величини. Проте вартість визначається не індивідуальними, а суспільно необхідними витратами, так як згадана конкуренція між товарами на ринку вирівнює різні індивідуальні витрати у суспільну, або ринкову вартість. Однак технічно передові підприємства одержують додатковий прибуток як різницю між низькими індивідуальними та більш високими суспільно необхідними витратами, що складають ринкову вартість. I знову ж таки навпаки, технічно та організаційно відсталі підприємства позбавляються частини індивідуальної вартості своїх товарів, що призводить в результаті до не одержання прибутків, а то й збитків. Міжгалузева конкуренція характеризується як конкуренція між товаровиробниками різних галузей за найбільш прибуткове використання всіх наявних ресурсів підприємства. Товари різних галузей обмінюються не просто як продукти праці а як вартості. [4,c.65 ]. Підприємство при цьому домагається зростання такого рівня прибутку, який повністю покривав величину витрат підприємства і забезпечував прибуток. Адже як відомо, що кожен товаровиробник зацікавлений у збереженні і розширенні ринку збуту виробленої ним продукції, тому постійно веде конкурентну боротьбу за споживача. Сьогодні в ринку існують відомі нам два методи такої боротьби, це цінова і нецінова конкуренція. Щодо цінової конкуренції то це вид конкурентної боротьби за допомогою зміни цін на товари. При ціновій конкуренції основним засобом суперництва $є$ зниження цін на товари підприємства відносно цін на подібну продукцію в конкурентів. При застосуванні цінової конкуренції найбільш поширеним $є$ встановлення цін зі знижками, а саме це знижки за прискорення оплати, знижки за платіж готівкою, знижки за кількість товару або серійність та ін. Даний спосіб передбачає зменшення ціни на продукт до певного рівня та при цьому беруть до уваги ціни конкурентів, що пропонують аналогічні товари, та витіснення їх з ринку. Потім ціни підіймаються знову, і підприємство, що застосовує цей спосіб, отримує прибутки на завойованій частці ринку. [3, с. 18]. Однак, як свідчить практичний досвід, що досить значне зниження цін може спричинити обернену реакцію покупців, а саме покупці перестануть купувати. Тобто застосовуючи спосіб цінової конкуренції необхідно виходити з того, щоб ціни на продукції задовольняли покупців і не були збитковими для підприємства. Нами вивчено 3 цією метою відповідний розрахунок, що одержав назву цінової конкурентоспроможності товару і визначається за такою формулою: Ц ЦК $=(Ц-C)$ : Ц x $100=\%$. Де : ЦК - цінова конкурентоспроможність, Ц - ціна, С - собівартість. Одержаний результат у відсотках означає, що підприємство має економічну можливість на такий відсоток знизити ціну проти рівня ринкової ціни і не мати при цьому збитку. Щодо особливостей і значення нецінової конкуренції. Вона застосовується тоді якщо ціновий фактор вичерпує свої можливості, тоді і потрібно застосовувати нецінову конкуренцію, яка базується на підвищенні якості продукції, впровадження нових технологій, збільшення кількості асортименту продукції та ін. Поряд 3 поліпшенням якісних показників продукції та поліпшеного дизайну нецінова конкуренція широко використовує дійове рекламноінформаційне забезпечення, маркетингові програми, продуктові й технологічні інновації, перспективність продукції, що дає змогу збільшувати обсяги іiї продажу без зниження ціни порівняно з конкурентами. Важливим при цьому також $є$ те, що умови продажу можуть включати у себе як високий рівень обслуговування покупця, так i підвищене гарантійне та поточне обслуговування придбаного товару. Досліджуючи дане питання приходимо до висновку, що при неціновій конкуренції роль ціни не зменшується, проте на перший план виступають споживчі властивості товару, які містять не лише набір техніко-економічних параметрів, а й певний рівень умов постачання, технічне обслуговування тощо. [3, с. 69]. Підсумовуючи роль і значення цінової i нецінової конкуренції то слід відмітити, що сучасний стан конкуренції на споживчому ринку України характеризується переважним розвитком цінової конкуренції між окремими продавцями товарів. У підсумку хочемо загострити увагу на позитивній ролі конкуренції в умовах ринку, яка вимагає - впровадження нової техніки і технології, 
розвиток науково-дослідних i дослідно-конструкторських розробок, впровадження нових форм і методів організації виробництва і праці, підвищення кваліфікації та перепідготовки працівників, розвиток інформаційної системи на підприємствах, а також пошук оптимальних критеріїв виробництва, економію всіх видів ресурсів та удосконалення управління виробництвом. В період підготовки даної публікації нами вивчалися приклади ефективних методів господарювання окремими підприємствами Волинської області в яких домінуючим принципом $\epsilon$ забезпечення конкурентоспроможності виробленої продукції. Для прикладу слід віднести такі сільськогосподарські підприємства як ім. Шевченка та ім. Івана Франка Горохівського району, «Пятидні» Володимир-Волинського, сільгосппідприємства «Рать» та « Городище» Луцького району.

Висновки. В даній статті окреслено сутність і зміст конкуренції, а також методи управління конкурентоспроможністю продукції підприємств в ринкових умовах. Адже нинішня тенденція в розвитку ринкових відносин змушує вітчизняні підприємства пристосовуватися до специфіки як внутрішнього так і міжнародного ринку, що потребує нових конкурентних відносин, нової структуризації виробництва продукції та надання послуг. На сучасному етапі конкуренція є важливим і дієвим механізмом, який забезпечує високу ефективність, пропорційність та динамічність ринкових відносин як у галузі виробництва, так і реалізації продукції. Пріоритетним питанням у цьому напрямі $\epsilon$ забезпечення конкурентоспроможності національного виробника на інноваційній основі, досягнення високого рівня випуску продукції і забезпечення прибутку. В публікації відображено як теоретичні так і методичні положення конкуренції, а також окремі пропозиції щодо забезпечення конкурентоспроможності вітчизняних підприємств в умовах ринку.

\section{Список бібліографічного опису:}

Мазаракі А.А. та ін. Економіка торговельного підприємства. /Під ред. Н.М. Ушакової . К.: “Хрещатик”, 1999. - 800с. Бланк И.А. Торговый менеджмент. - Киев: Украинско-Финский институт менеджмента и бизнеса, 1997. - 408 с.

Лукашевич В.В. Основы менеджмента в торговле. - М.: Экономика, 1996. - 191 с.

Экономика торгового предприятия: Учеб. Пособ. С.Н. Лебедева, Н.А. Казиначикова и др.- 2-е изд. - Минск: Новое знание, 2002.

Пигунова О.В. Стратегия коммерческой деятельности предприятия розничной торговли. - М.: Издательско-книготорговій центр “Маркетинг”, 2002.

6. Економіка підприємства: Підручник за заг. ред. С. Ф. Покропивного - Вид 2-ге. - К.: КНЕУ, 2000.

7. Економіка підприємства. Збірник практичних задачі і конкретних ситуацій: Навч. Посібник. За ред. С. Ф. Покропивного. - К.: КНЕУ, 1999.

8. Економіка підприємства: Навч. -метод. посібник для самостійного вивчення дисциплін О. Г. Швиданенко та інші - К.: КНЕУ, 2000. 9. Економіка підприємства: Структурно-логічний навч. Посібник за ред. С. Ф. Покропивного. - К.: КНЕУ, 2001. - 457 с.

10. Мадзігон В.В. Теорія попиту і пропозиції ринкової економіки на товари і послуги. Молодь і ринок. - 2011. - №2(73). - С. 41 - 46.

11. Загальна економіка: Підручник / За ред. І.Ф.Радіонової - К.- Подільський, 2002.

\section{References:}

1. Mazaraki A.A. etc. Economy of trading enterprise. / Ed. N.M. Ushakova / - K .: Khreschatyk, 1999. - 800 p.

2. Blank IA Trade management. Kiev: Ukrainian-Finnish Institute of Management and Business, 1997. - $408 \mathrm{sec}$.

3. VV Lukashevich Fundamentals of management in trade. - Moscow: Economics, 1996. - 191 p. 4. Economics of Trade Enterprise: Textbook.

Tooltip / S.N. Lebedeva, N.A. Kazinachikova et al. - 2nd ed. - Minsk: New Knowledge, 2002.

5. Pigunova OV Strategy of commercial activity of the retail trade enterprise. - M .: Marketing Publishing Center, 2002.

6. Economics of the enterprise: Textbook / For the total. ed. SF Pokropivny - View of the 2nd. - K .: KNEU, 2000.

7. The economy of the enterprise. Collection of practical problems and specific situations: Educ. Manual. / Edited SF Pokropivny. - K .: KNEU, 1999.

8. Enterprise Economics: Educ. -method. a manual for independent study of disciplines / OG Shvydanenko and others - K .: KNEU, 2000.

9. Economics of the enterprise: Structural and logical teaching. manual / Edited by SF Pokropivny. - K .: KNEU, 2001. - 457 p.

10. Madigon V.V. The theory of supply and demand in entrepreneurship in the realities of market economy for goods and services. // Youth and the market. - 2011. - №2 (73). - pp. 41 - 46. 11.General Economics: Textbook / Ed. IF Radionova - K.- Podilsky, 2002.

Рецензент д.е.н., професор Ковальська Л.Л. 